Archive for

Organic Chemistry

Arkivoc 2017, part ii, 260-271

\title{
Improved synthetic routes to the selenocysteine derivatives useful for Boc-based peptide synthesis with benzylic protection on the selenium atom
}

\author{
Shingo Shimodaira and Michio Iwaoka*
}

Department of Chemistry, School of Science, Tokai University, Kitakaname, Hiratsuka-shi, Kanagawa 259-1292, Japan

\section{Email: miwaoka@tokai.ac.jp}

Dedicated to Prof. Jacek Młochowski on the occasion of his $80^{\text {th }}$ birthday

Received 07-18-2016

Accepted 09-11-2016

Published on line 09-25-2016

\section{Abstract}

Selenocysteine (Sec) derivatives, i.e., Boc-Sec(MBn)-OH (1) and Boc-Sec(MPM)-OH (2), which are useful for chemical synthesis of selenopeptides, were obtained from L-serine in five steps with total yields of $73 \%$ and $74 \%$, respectively. The enantiomeric excesses were confirmed to be $>99 \%$ e.e. by optical resolution using a chiral column on HPLC. On the other hand, for the case of a Fmoc-protected Sec derivative, i.e., Fmoc$\mathrm{Sec}(\mathrm{MPM})-\mathrm{OH}$, similar reactions resulted in low yields and partial racemization taking place.

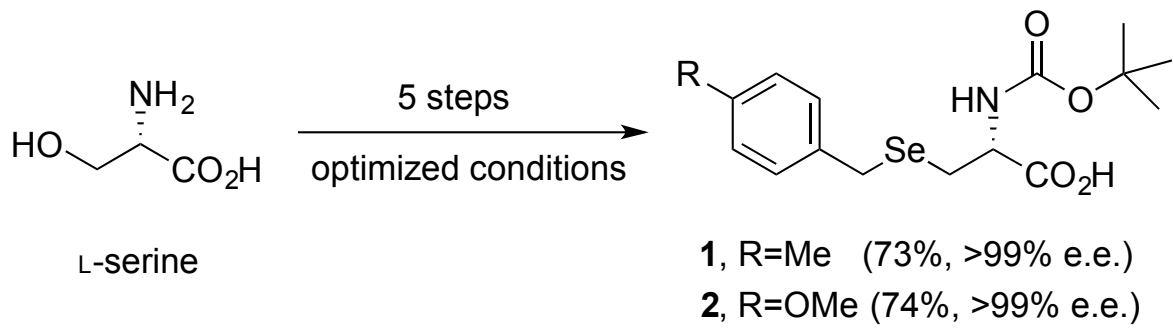

Keywords: Selenocysteine, iodination, selenolate, optical resolution, racemization, peptide synthesis 


\section{Introduction}

Selenocysteine $(\mathrm{Sec}, \mathrm{U})^{1}$ is a unique natural amino acid, which contains selenium, an essential micronutrient for animals, and is directly incorporated into proteins according to the UGA codon on mRNA. Thus, it is referred to as the $21^{\text {st }}$ proteinogenic amino acid. In mammals, Sec is involved at the active site of various selenoenzymes, ${ }^{2}$ such as glutathione peroxidase (GPX) and thioredoxin reductase (TrxR). Much recent research has focused on developing new small organoselenium compounds that mimic the functions of these selenoenzymes. ${ }^{3,4}$ Various types of aromatic and aliphatic selenium compounds have already been inspected as such mimics. However, there are only a few reports on the application of Sec-containing peptides (i.e., selenopeptides) as selenoenzyme models. ${ }^{5-8}$

Although it is known that selenoproteins are expressed in the ribosome recruiting Ser-tRNA ${ }^{\mathrm{Sec}}$, which has an anti-codon complementary to UGA, the mechanism of Sec biosynthesis is complicated involving a number of enzymes. ${ }^{9}$ Therefore, preparation of recombinant selenopeptides by site-directed mutagenesis applying molecular biology technology is still not easy. ${ }^{10}$ In the meantime, a conventional method for the chemical synthesis of selenopeptides ${ }^{11}$ is advantageous because it allows sequential introduction of a variety of amino acids, including non-natural amino acids, with an arbitrary order to a growing peptide chain based only on chemical reaction processes. Accordingly, the chemical methods, most frequently a solid-phase peptide synthesis (SPPS) method, have been applied for the synthesis of various selenopeptides. ${ }^{12,13}$ Long $^{2}$ selenopeptides that possess a couple of Sec residues along the chain have also been synthesized by application of selenocysteine-based native chemical ligation (Sec-NCL). ${ }^{14-16}$

To synthesize selenopeptides in a flask, particular Sec derivatives have to be utilized. For example, $\mathrm{N}$-(tertbutoxycarbonyl)-Se-(p-methylbenzyl)-L-selenocysteine (Boc-Sec(MBn)-OH, 1) and $\mathrm{N}$-(tert-butoxycarbonyl)-Se(p-methoxybenzyl)-L-selenocysteine (Boc-Sec(MPM)-OH, 2) (Figure 1), which have Boc protection on the amino group and MBn or MPM protection on the selenium atom, are useful for Boc-based selenopeptide synthesis as the MBn and MPM groups in these targets can be deprotected under satisfactory conditions in the final step of selenopeptide synthesis. ${ }^{17}$ Although several methods are available for preparation of such Sec derivatives, ${ }^{13}$ their synthesis frequently encounters problems such as low yields, difficulty in the experimental procedures, and racemization at the $\alpha$ carbon atom. Even in the conventional method starting from commercially available L-selenocystine, ${ }^{18}$ the starting material is a little expensive to prepare in sufficient amount of the protected selenocysteine derivatives for SPPS. In this paper, with modification of Metanis' scheme previously reported for the synthesis of $\mathbf{1}^{12}$ and Braga's procedure of selenation on the side-chain of serine derivatives, ${ }^{19}$ we present improved synthetic routes to $\mathbf{1}$ and $\mathbf{2}$ with reasonably yields and high enantiomeric purities, starting from L-serine (3).

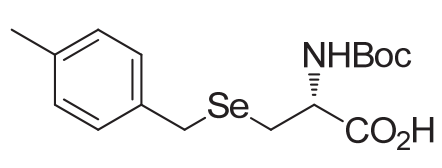

Boc-Sec(MBn)-OH (1)

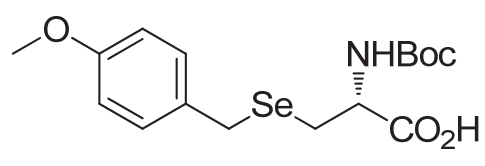

Boc-Sec(MPM)-OH (2)

Figure 1. Selenocysteine derivatives useful for Boc-based SPPS of selenopeptides. The $p$-methoxybenzyl group (MPM) is also sometimes abbreviated as Mob or PMB. 


\section{Results and Discussion}

Metanis $^{12}$ reported an efficient synthetic scheme for Boc-Sec(MBn)-OH (1), which was subsequently applied for Boc-based SPPS of seleno-glutaredoxin 3 analogues having Sec residue(s) in place of the active-site cysteine (Cys) residue(s). In Metanis' scheme, the hydroxyl group of Boc-protected serine methyl ester (i.e., Boc-Ser-OMe, 5) was activated to a tosylate and then selenated with $p$-methylbenzyl selenol $(\mathrm{MBnSeH})$ to yield a Sec derivative (i.e., Boc-Sec(MBn)-OMe, 7), which was hydrolyzed to 1 by the use of trimethyltin hydroxide $\left(\mathrm{Me}_{3} \mathrm{SnOH}\right)$ in the final step. However, strict control of the reaction conditions was necessary in preparation of the selenol (i.e., $\mathrm{MBnSeH}$ ), and the total yield of 1 was not high (52\% from 5). On the other hand, Braga ${ }^{19}$ succeeded in obtaining various selenocysteine derivatives, i.e., Boc-Sec(R)-OMe, where $R=$ phenyl, benzyl, p-methoxybenzyl (MPM), etc., more easily by reacting a mesylate, i.e., Boc-Ser(Ms)-OMe, with the corresponding selenolate ( $\left.\mathrm{RSe}^{-}\right)$, which was generated in situ from diselenide (RSeSeR) by reduction with sodium borohydride $\left(\mathrm{NaBH}_{4}\right)$. In these reports, a tosylate or a mesylate derived from L-serine (3) was employed as an active substrate for selenation.

Furthermore, a halogenated alanine derivative, i.e., Boc- $\beta-X-A l a-O M e ~(X=C l, B r$, or $\mathrm{I})$, has been another choice of an amino acid substrate as a target of selenation. Indeed, in the early Sec syntheses, chloroalanine derivatives were reacted with selenating agents, such as $\mathrm{Na}_{2} \mathrm{Se}_{2} \cdot{ }^{20-22}$ Later, more reactive bromoalanines were utilized for the synthesis of Sec derivatives. ${ }^{15,23-26}$ In this context, iodoalanine derivatives should be much better selenium acceptors. Indeed, Stocking ${ }^{23}$ used an iodoalanine derivative, which was obtained from serine via a tosylated intermediate, to synthesize Sec derivatives. The same scheme was applied for preparation of ${ }^{77}$ Se-enriched selenocysteine. ${ }^{27}$ Kawai $^{28}$ obtained iodoalanine derivatives directly from the corresponding serine derivatives by use of $\mathrm{N}$-iodosuccinimide and applied them for the synthesis of Sec derivatives. Iwaoka $^{29,30}$ reported the conversion of cysteine derivatives to Sec derivatives via an active iodoalanine intermediate. Except for these examples, use of iodoalanine derivatives as selenium acceptors in the synthesis of Sec derivatives has not yet been extensively studied, in comparison with the use of chloroalanine and bromoalanine derivatives. We describe below our investigations of the usability of iodoalanine derivatives as active intermediates for the synthesis of $\mathbf{1}$ and $\mathbf{2}$.

According to Metanis' method, ${ }^{12}$ the amino group of L-serine (3) was protected with Boc, and the obtained carbamate $\mathbf{4}$ was converted into methyl ester $\mathbf{5}$ (Scheme 1). The Ser derivative thus protected was tosylated to 6 and then selenated to $\mathbf{7}$ by reaction with a selenolate, which was generated from di( $p$-methylbenzyl) diselenide ( $\mathrm{MBnSeSeMBn}$ ) and $\mathrm{NaBH}_{4}$ in $\mathrm{MeOH}$, according to a similar procedure reported by Braga. ${ }^{19}$ Since the isolated yield of methylbenzyl selenide 7 was low (26\%), the selenation conditions were subsequently optimized. It was found that the yield increases up to $69 \%$ in $\mathrm{MeOH}: \mathrm{Et}_{2} \mathrm{O}=2: 3$ by using two equivalents of the selenolate (i.e., $\mathrm{MBnSe}^{-}$) with respect to tosylate $\mathbf{6}$. On the other hand, when methyl ester $\mathbf{5}$ was converted into iodoalanine derivative 8 by Appel reaction ${ }^{31}$ and subsequently into 7 under similar selenation conditions as above, but by use of only one equivalent of $\mathrm{MBnSe}^{-}$, the same product (i.e. 7) was obtained in $83 \%$ yield from 5, suggesting that the iodide is a more effective substrate than the tosylate for selenation. Although iodide $\mathbf{8}$ could be isolated by silica gel column chromatography, we applied here a short silica gel column and the obtained crude material was employed for subsequent selenation without further purification. Indeed, when iodide 8 was fully purified, the yield of 7 decreased from $83 \%$ to $75 \%$ probably due to a loss during the purification of 8. Obtained 7 was hydrolyzed to the target compound (i.e. 1) by use of $\mathrm{Me}_{3} \mathrm{SnOH}$ according to Metanis' method. ${ }^{12}$ Total yields of 1 from L-serine (3) were 55\% and 73\% for the routes through tosylate 6 and iodide $\mathbf{8}$, respectively. It is worth noting that the yield through the tosylate route was slightly improved from Metanis' yield (45\% total yield), ${ }^{12}$ owing to optimization of the reaction conditions in each step as well as 
application of a selenolate instead of an air-sensitive selenol as a selenating agent. Similarly, the other target $\mathbf{2}$ was obtained from 3 in a total yield of $74 \%$ through the iodide route by use of di( $p$-methoxybenzyl) diselenide (MPMSeSeMPM) instead of MBnSeSeMBn. The total yield was comparable to that from selenocystine (79\%) reported by Flögel. ${ }^{18}$ The optical purities of $\mathbf{1}$ and $\mathbf{2}$ thus obtained were determined to be $>99 \%$ e.e. by the optical resolution using a chiral column on HPLC as shown in Figures 2 and 3.
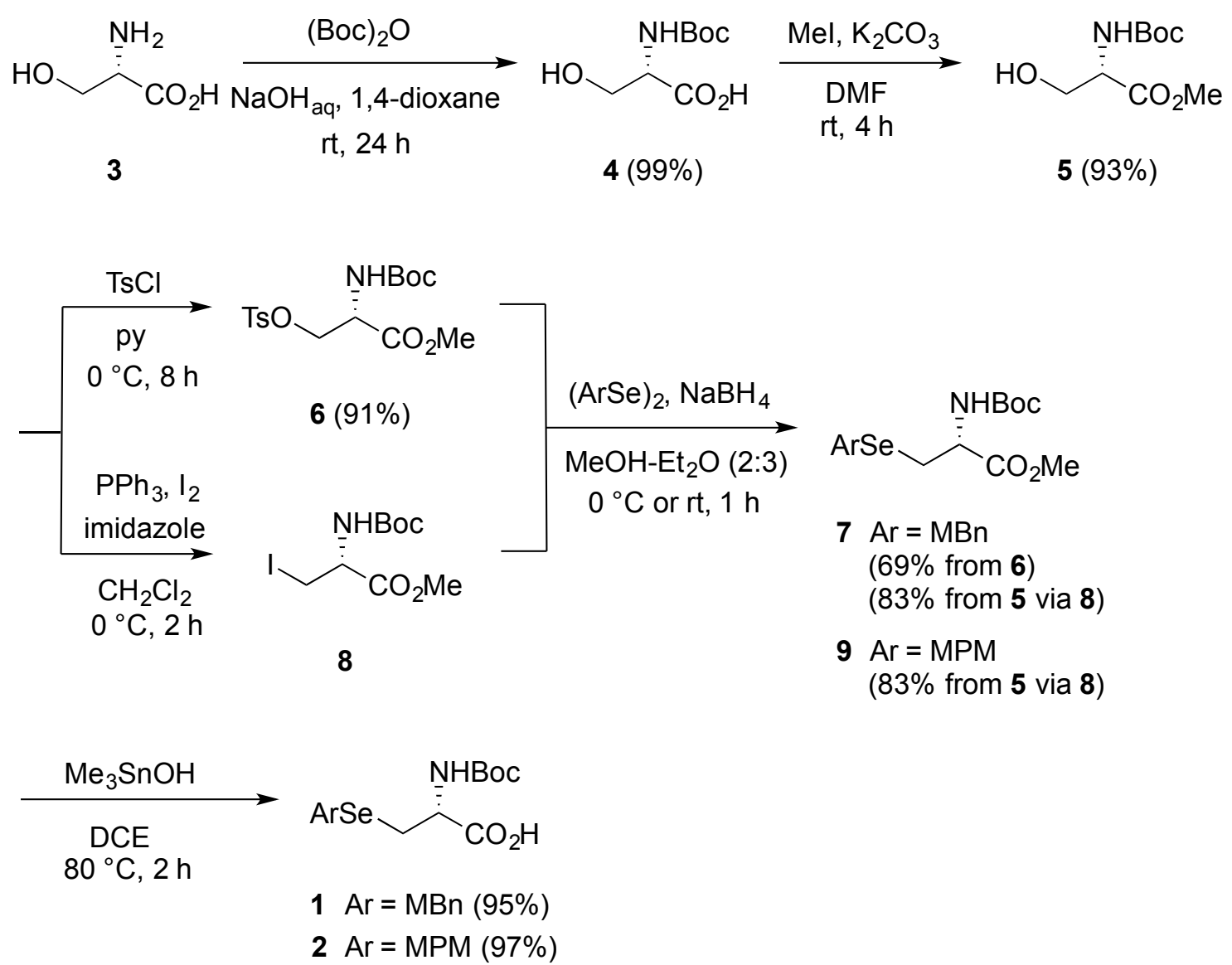

Scheme 1. Optimized routes for the synthesis of $\mathbf{1}$ and $\mathbf{2}$ from L-serine (3).

Having succeeded in significant improvement of the synthetic methods to prepare selenocysteine derivatives 1 and 2, we subsequently applied a similar synthetic scheme to another selenocysteine derivative (i.e. 15) that is useful for 9-fluorenylmethoxycarbonyl (Fmoc)-based SPPS (Scheme 2). L-serine (3) was converted into Fmoc-Ser-OMe (11) in a good yield through carbamate 10. Then, methyl ester 11 was tosylated (72\%), and the obtained 12 was reacted with $\mathrm{MPMSe}^{-}$to give Fmoc-Sec(MPM)-OMe (13) in 78\% yield. On the other hand, when methyl ester 11 was converted into iodide 14 and then selenated by use of MPMSe', selenide 13 was obtained in a low yield (34\% in two steps). It may be possible to increase the yields by extensive examination of the reaction conditions, but we did not perform this because selenide 13 was found to be partially racemized: ca. $50 \%$ e.e. obtained through tosylate $\mathbf{1 2}$ and 80 to $98 \%$ e.e. obtained through iodide 14. It should also be noted that iodide $\mathbf{1 4}$ is an unstable compound decomposing slowly on silica gel. We assume that the racemization occurs through deprotonation at the $\alpha$-carbon atom producing dehydroalanine intermediates under the conditions applied (i.e. $\mathrm{NaBH}_{4}+$ diselenide). Fortunately, the racemization problem could be overcome by recrystallizing $\mathbf{1 3}$ more than twice from dichloromethane-hexane (see Figure 4), though the recrystallization resulted in a decrease of the yield: recovery of enatiomerically pure 
13 was about $60 \%$ after two rounds of crystallization. Compound 13 thus obtained was hydrolyzed to Fmoc$\mathrm{Sec}(\mathrm{MPM})-\mathrm{OH}(15)$ in a high yield (91\%) by using $\mathrm{Me}_{3} \mathrm{SnOH}$.

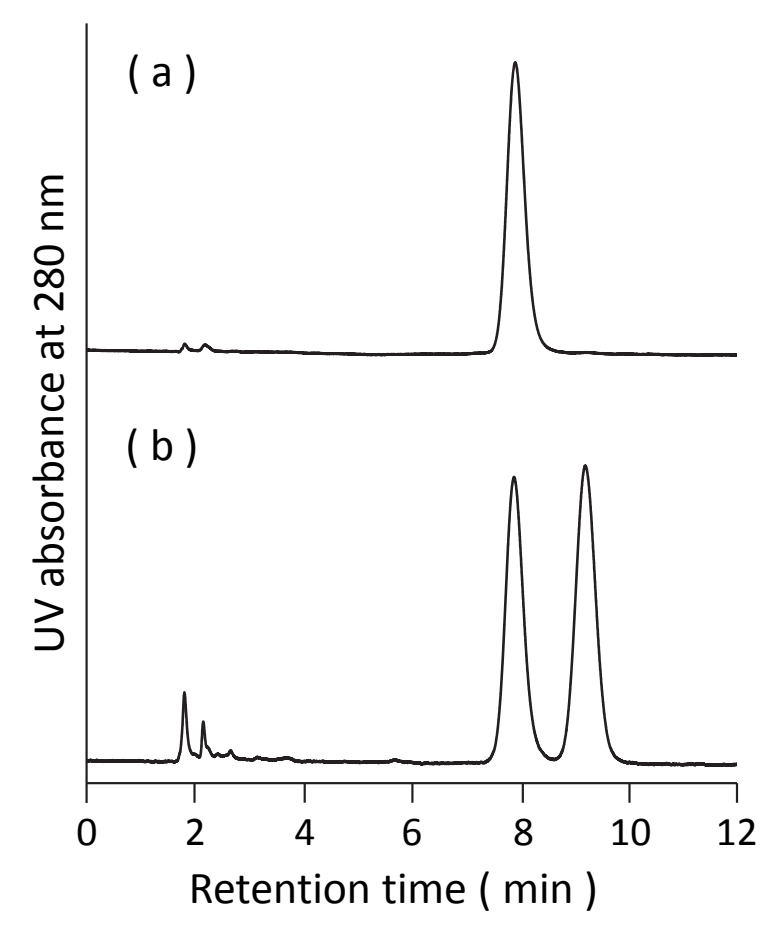

Figure 2. Optical resolution of 1 by using a chiral column on HPLC. (a) 1 obtained by Scheme 1. (b) Racemic 1.

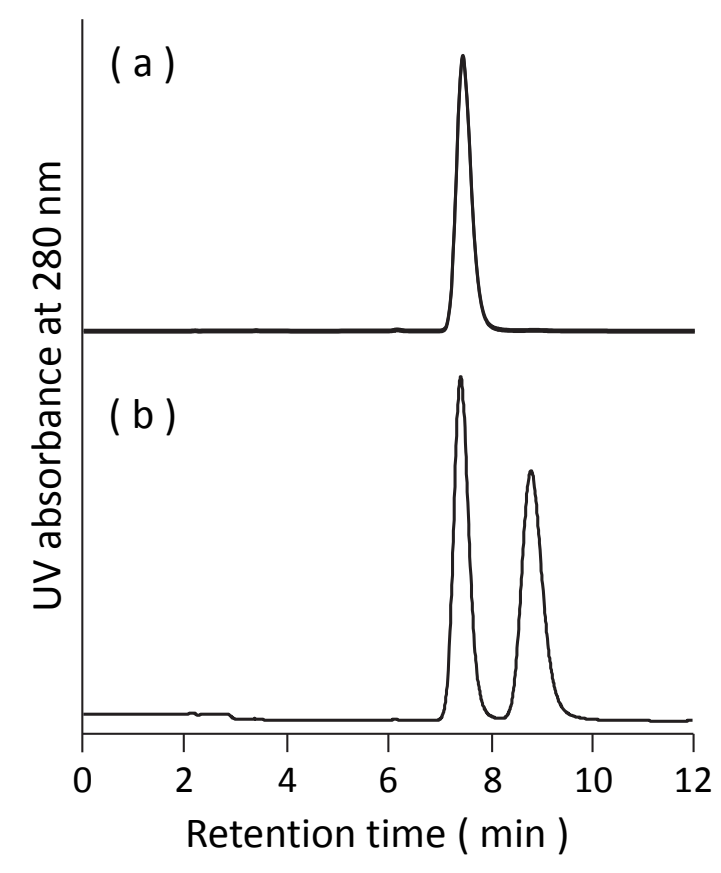

Figure 3. Optical resolution of $\mathbf{2}$ by using a chiral column on HPLC. (a) $\mathbf{2}$ obtained by Scheme 1. (b) Racemic $\mathbf{2}$.

The above results indicate that when a selenolate nucleophile (i.e., $\mathrm{RSe}^{-}$) is applied as a selenating agent for Fmoc-protected 12 and 14, racemization would take place to significant extent, whereas such racemization does not occur for Boc-protected alternatives due probably to larger steric hindrance by the Boc group. Thus, 
the synthetic scheme improved in this study would be usable only for the synthesis of Sec derivatives with Boc protection.
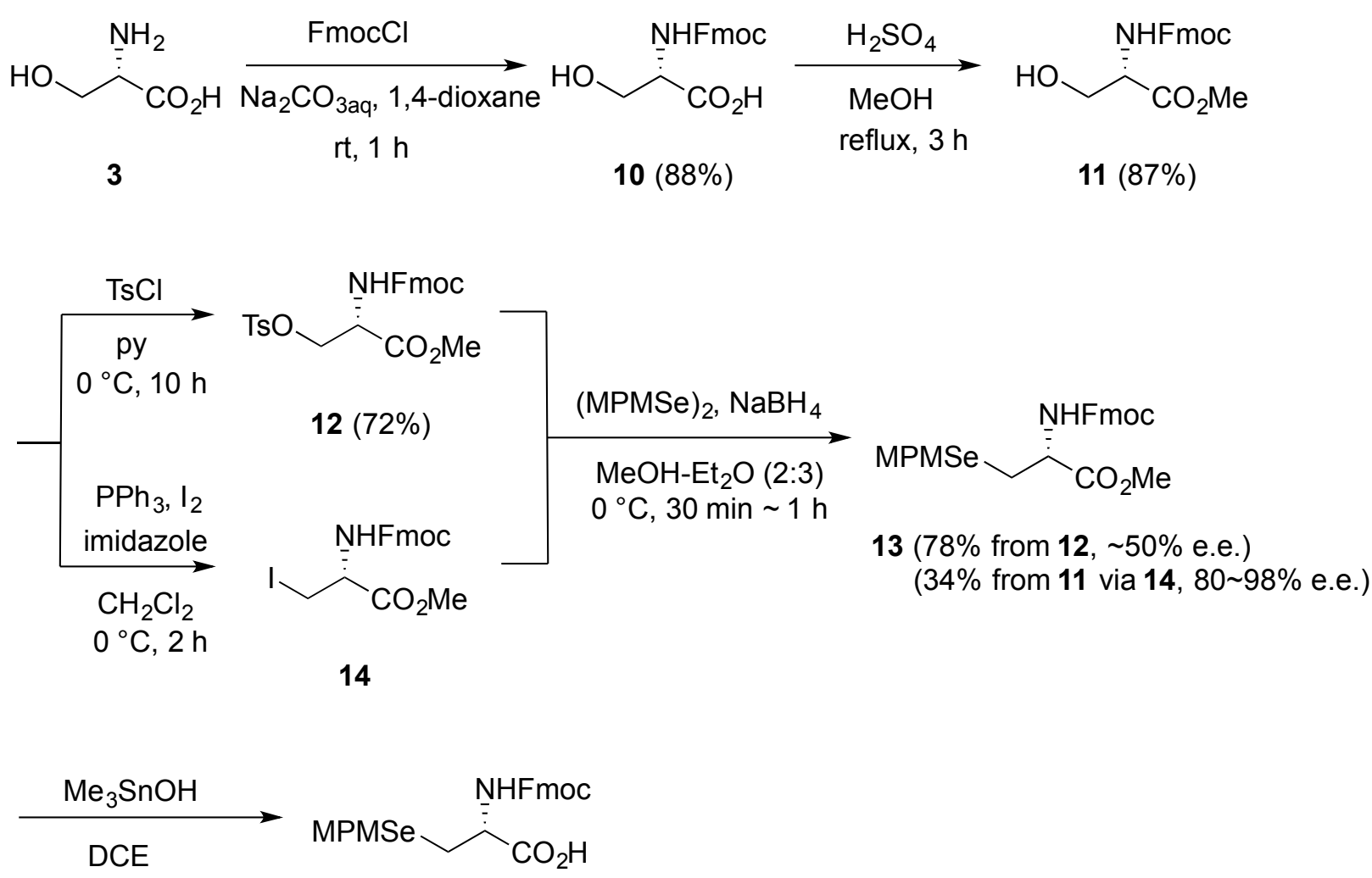

$35^{\circ} \mathrm{C}$, overnight

$15(91 \%)$

Scheme 2. Synthesis of Fmoc-Sec(MPM)-OH (15).

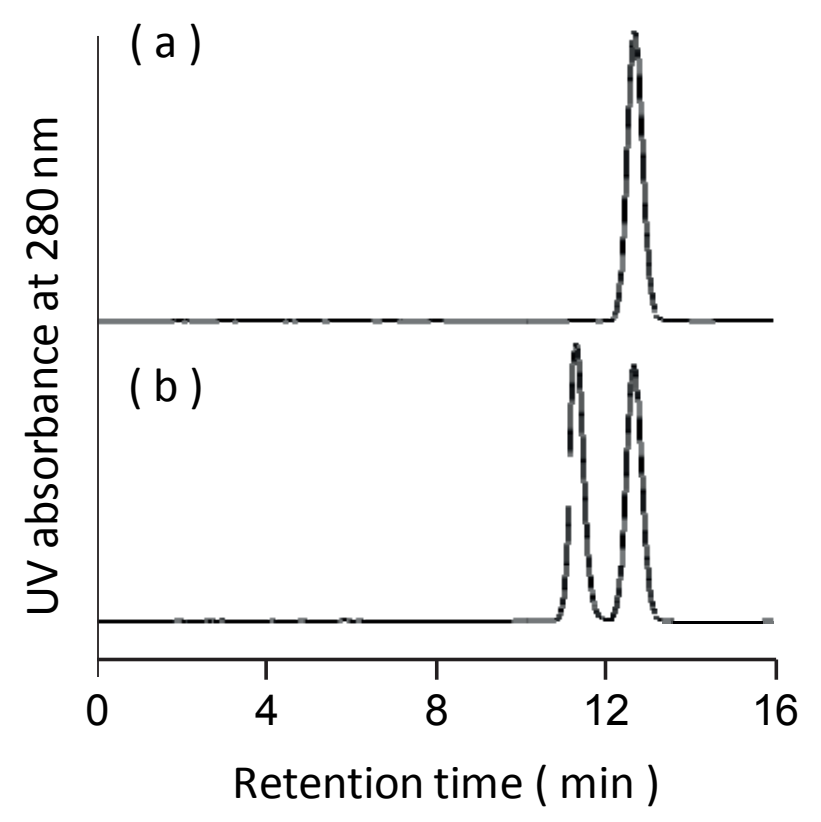

Figure 4. Optical resolution of 15 by using a chiral column on HPLC. (a) 15 obtained by Scheme 2 through 14. Compound 13 was recrystallized twice from dichloromethane-hexane. (b) Racemic 15. 


\section{Conclusion}

With modifications of the methods previously reported by Matenis ${ }^{12}$ and Braga, ${ }^{19}$ we optimized the synthetic routes to Sec derivatives, which are useful for Boc-based selenopeptide synthesis. As a result, we have succeeded in a significant increase of the yields of $\mathbf{1}$ and $\mathbf{2}$ by selecting the route through an iodide intermediate 8. The total yields of $\mathbf{1}$ and $\mathbf{2}$ from L-serine (3) were $73 \%$ and $74 \%$, respectively, without incurring racemization. Since an excess amount of $\mathrm{Sec}$ derivatives are necessary for high-yield synthesis of selenopeptides, the improved routes reported here will be valuable for promoting the research that utilizes various selenopeptides as selenoenzyme models ${ }^{5}$ or for other purposes. ${ }^{12-16}$ On the other hand, for the case of Fmoc-protected Sec derivatives, it was found that a similar route through an iodide intermediate 14 (and tosylate 12) and subsequent selenation with a selenolate nucleophile ( $\mathrm{RSe}^{-}$) does not work well, resulting in a low yield and partial racemization taking place. However, the racemization problem can be overcome by repeated recrystallization, though the yield decreases. Application of $\mathbf{1}$ and $\mathbf{2}$ to the synthesis of designed selenopeptides as well as further efforts to find an efficient synthetic route to $\mathbf{1 5}$ are being explored in our laboratory.

\section{Experimental Section}

General. ${ }^{1} \mathrm{H}(500 \mathrm{MHz}),{ }^{13} \mathrm{C}(125.8 \mathrm{MHz})$, and ${ }^{77} \mathrm{Se}(95.4 \mathrm{MHz}) \mathrm{NMR}$ spectra were recorded at $298 \mathrm{~K}$. The chemical shifts $(\delta)$ are expressed in ppm against solvent peaks as internal references for ${ }^{1} \mathrm{H}$ and ${ }^{13} \mathrm{C} N M R$. For ${ }^{77}$ Se NMR, diphenyl diselenide was used as an external standard. The coupling constants $(J)$ are reported in $\mathrm{Hz}$. Reactions were monitored by thin-layer chromatography (TLC). All chemicals were used as purchased without further purification.

$\mathbf{N}$-(tert-Butoxycarbonyl)-L-serine (4). To a solution of L-serine (3) $(2.00 \mathrm{~g}, 19.0 \mathrm{mmol})$ in $1 \mathrm{M} \mathrm{NaOH}(22 \mathrm{~mL})$ cooled on an ice bath was slowly added a solution of di-tert-butyl dicarbonate (5.4 mL, $23.5 \mathrm{mmol}$ ) in 1,4dioxane $(16 \mathrm{~mL})$. After stirring for $30 \mathrm{~min}$ on an ice bath, the mixture was stirred for $24 \mathrm{~h}$ at rt. The reaction mixture was evaporated to remove solvent, and the resulting solution was extracted with diethyl ether to remove ether-soluble byproducts. A $1 \mathrm{M}$ potassium hydrogen sulfate solution was added to the aqueous layer, and the mixture was extracted with EtOAc. The organic layer was washed with brine, dried over $\mathrm{MgSO}_{4}$, and evaporated to give 4 as a colorless oil (3.90 g, 99\%). The spectral data of 4 were identical to those in the literature. ${ }^{25}$ The purity was confirmed by ${ }^{1} \mathrm{H}$ NMR.

$\mathbf{N}$-(tert-Butoxycarbonyl)-L-serine methyl ester (5). To a solution of 4 (1.26 g, $6.1 \mathrm{mmol})$ and potassium carbonate $(0.91 \mathrm{~g}, 6.6 \mathrm{mmol})$ in DMF $(12 \mathrm{~mL})$ cooled on an ice bath was added a solution of iodomethane $(0.80$ $\mathrm{mL}, 12.8 \mathrm{mmol}$ ) in DMF $(6 \mathrm{~mL})$. After stirring for $30 \mathrm{~min}$ on an ice bath, the mixture was stirred for $4 \mathrm{~h}$ at $\mathrm{rt}$. Precipitates were filtered off, and the filtrate was added with water and extracted with EtOAc. The organic layer was washed with water and brine, dried over $\mathrm{MgSO}_{4}$, and evaporated. The obtained colorless oil was purified by silica gel column chromatography (hexane:EtOAc $=1: 1$ ) to give 5 as a colorless oil $(1.24 \mathrm{~g}, 93 \%)$. The spectral data of 5 were identical to the literature, ${ }^{25}$ and the purity was confirmed by ${ }^{1} \mathrm{H}$ NMR.

$\boldsymbol{N}$-(tert-Butoxycarbonyl)-O-(p-toluenesulfonyl)-L-serine methyl ester (6). To a solution of 5 (0.67 g, $3.1 \mathrm{mmol})$ in pyridine $(10 \mathrm{~mL})$ cooled on an ice bath was added $p$-toluenesulfonyl chloride $(3.0 \mathrm{~g}, 15.7 \mathrm{mmol})$. After stirring for $8 \mathrm{~h}$ on an ice bath under nitrogen atmosphere, $\mathrm{Et}_{2} \mathrm{O}(10 \mathrm{~mL})$ was added to the solution, and the mixture was further stirred at $\mathrm{rt}$ for $14 \mathrm{~h}$. The resulting yellow solution was washed with water, $10 \%$ potassium 
hydrogen sulfate, saturated sodium bicarbonate, and brine. The ethereal layer was dried over $\mathrm{MgSO}_{4}$ and evaporated. The obtained colorless oil was purified by silica gel column chromatography (hexane:EtOAc $=2: 1$ ) to give 6 as a white solid (1.05 g, 91\%). The spectral data of 6 were identical to the literature. ${ }^{32}$ The purity was $^{2}$ confirmed by ${ }^{1} \mathrm{H}$ NMR.

$\mathbf{N}$-(tert-Butoxycarbonyl)-Se-(p-methylbenzyl)-L-selenocysteine methyl ester (7). To a solution of 6 (102 mg, $0.27 \mathrm{mmol})$ and bis-( $p$-methylbenzyl) diselenide $(103 \mathrm{mg}, 0.28 \mathrm{mmol})$ in $\mathrm{MeOH}(4 \mathrm{~mL})$ and $\mathrm{Et}_{2} \mathrm{O}(6 \mathrm{~mL}) \mathrm{was}$ added sodium borohydride until the solution color disappeared. After stirring for $1 \mathrm{~h}$, water was added to the resulting yellow solution, and the mixture was extracted with $\mathrm{Et}_{2} \mathrm{O}$. The organic layer was washed with brine, dried over $\mathrm{MgSO}_{4}$, and evaporated. The obtained yellow oil was purified by silica gel column chromatography (hexane:EtOAc $=4: 1$ ) to give 7 as a pale yellow solid (105 mg, 69\%). The spectral data of 7 were identical to the literature. ${ }^{12}$ The purity was confirmed by ${ }^{1} \mathrm{H} N M R .{ }^{1} \mathrm{H} N M R\left(\mathrm{CDCl}_{3}\right): \delta_{\mathrm{H}} 1.48(9 \mathrm{H}, \mathrm{s}, t \mathrm{Bu}), 2.34(3 \mathrm{H}, \mathrm{s}, p-\mathrm{Me}), 2.92$ $(2 \mathrm{H}, \mathrm{m}, \beta \mathrm{H}), 3.77(3 \mathrm{H}, \mathrm{s}, \mathrm{OMe}), 3.79\left(2 \mathrm{H}, \mathrm{s}, \mathrm{CH}_{2}\right), 4.63(1 \mathrm{H}, \mathrm{m}, \alpha \mathrm{H}), 5.32\left(1 \mathrm{H}, \mathrm{d}, J_{\mathrm{HH}} 7.5 \mathrm{~Hz}, \mathrm{NH}\right), 7.12\left(2 \mathrm{H}, \mathrm{d}, J_{\mathrm{HH}}\right.$ $7.9 \mathrm{~Hz}, \mathrm{ArH}), 7.19\left(2 \mathrm{H}, \mathrm{d}, J_{\mathrm{HH}} 7.9 \mathrm{~Hz}, \mathrm{ArH}\right) .{ }^{13} \mathrm{C} \mathrm{NMR}\left(\mathrm{CDCl}_{3}\right): \delta_{\mathrm{C}} 21.1,25.9,27.7,28.3,52.5,53.4,80.1,128.8$, 129.3, 135.6, 136.6, 155.1, 171.7. ${ }^{77}$ Se NMR $\left(\mathrm{CDCl}_{3}\right): \delta_{\text {se }} 216.5$.

Synthesis of 7 via iodide 8. Under nitrogen atmosphere, triphenyl phosphine $(911 \mathrm{mg}, 3.5 \mathrm{mmol})$ and imidazole ( $237 \mathrm{mg}, 3.5 \mathrm{mmol}$ ) were dissolved in dry dichloromethane $(12 \mathrm{~mL})$. To this solution cooled on an ice bath was added iodine ( $899 \mathrm{mg}, 3.5 \mathrm{mmol})$. The mixture was stirred at $\mathrm{rt}$ for $10 \mathrm{~min}$ and then cooled on an ice bath again. To the resulting yellow suspension was added a solution of 5 (507 $\mathrm{mg}, 2.3 \mathrm{mmol}$ ) in dry dichloromethane $(8 \mathrm{~mL}$ ). After stirring for $2 \mathrm{~h}$ on an ice bath, the reaction mixture (a yellow suspension) was passed through a short silica gel column (hexane: $\operatorname{Et}_{2} \mathrm{O}=1: 1$ ) to remove the precipitates. The eluent was evaporated to give crude 8 as an orange oil. Obtained 8 and bis-( $p$-methylbenzyl) diselenide (385 mg, 1.1 $\mathrm{mmol}$ ) were dissolved in a mixture of $\mathrm{MeOH}(8 \mathrm{~mL})$ and $\mathrm{Et}_{2} \mathrm{O}(12 \mathrm{~mL})$. The solution was cooled on an ice bath and then added with sodium borohydride until the solution color disappeared. After stirring for $1 \mathrm{~h}$, water was added to the resulting solution, and the mixture was extracted with EtOAc. The organic layer was washed with brine, dried over $\mathrm{MgSO}_{4}$, and evaporated. The obtained crude product (a yellow oil) was purified by silica gel column chromatography (hexane:EtOAc $=4: 1$ ) to give 7 as a pale yellow oil $(741 \mathrm{mg}, 83 \%$ from 5 ). When crude $\mathbf{8}$ was purified by silica gel column chromatography, the yield of $\mathbf{7}$ was decreased to $75 \%$ from $\mathbf{5}$. Identity and purity of $8^{31}$ were confirmed by ${ }^{1} \mathrm{H}$ NMR.

$\boldsymbol{N}$-(tert-Butoxycarbonyl)-Se-(p-methylbenzyl)-L-selenocysteine (1). To a solution of 7 (993 $\mathrm{mg}, 2.6 \mathrm{mmol}) \mathrm{in}$ dry 1,2-dichloroethane $(10 \mathrm{~mL})$ was added trimethyltin hydroxide $(1.32 \mathrm{~g}, 7.3 \mathrm{mmol})$. After stirring for $2 \mathrm{~h}$ at $80^{\circ} \mathrm{C}$, the mixture (a white suspension) was passed through a silica gel column (hexane:EtOAc $=4: 1$ to $0: 1$ ) to give 1 as a yellow oil or white solid (912 mg, 95\%). The spectral data of 1 were identical to the literature. ${ }^{12}$ The purity was confirmed by ${ }^{1} \mathrm{H}$ NMR and HPLC. ${ }^{1} \mathrm{H}$ NMR $\left(\mathrm{CDCl}_{3}\right): \delta_{\mathrm{H}} 1.48(9 \mathrm{H}, \mathrm{s}, t \mathrm{Bu}), 2.34(3 \mathrm{H}, \mathrm{s}, p-\mathrm{Me}), 2.95(2 \mathrm{H}$, $\left.\mathrm{d}, J_{\mathrm{HH}} 4.0 \mathrm{~Hz}, \beta \mathrm{H}\right), 3.82\left(2 \mathrm{H}, \mathrm{s}, \mathrm{CH}_{2}\right), 4.62(1 \mathrm{H}, \mathrm{m}, \alpha \mathrm{H}), 5.28\left(1 \mathrm{H}, \mathrm{d}, J_{\mathrm{HH}} 7.0 \mathrm{~Hz}, \mathrm{NH}\right), 7.11\left(2 \mathrm{H}, \mathrm{d}, J_{\mathrm{HH}} 7.9 \mathrm{~Hz}, \mathrm{ArH}\right)$, $7.19\left(2 \mathrm{H}, \mathrm{d}, J_{\mathrm{HH}} 7.9 \mathrm{~Hz}, \mathrm{ArH}\right) .{ }^{13} \mathrm{C} \mathrm{NMR}\left(\mathrm{CDCl}_{3}\right): \delta_{\mathrm{C}} 21.1,25.2,27.9,28.3,53.3,80.6,128.8,129.4,135.5,136.7$, 155.5, 175.4. ${ }^{77}$ Se NMR $\left(\mathrm{CDCl}_{3}\right): \delta_{\text {se }} 217.7$.

$\mathbf{N}$-(tert-Butoxycarbonyl)-Se-(p-methoxybenzyl)-L-selenocysteine methyl ester (9). Following similar procedures to those for the synthesis of $\mathbf{7}$ via iodide $\mathbf{8}$ (vide supra), selenide $\mathbf{9}$ was obtained from $\mathbf{5}$ as a yellow oil in $83 \%$ yield by use of bis-( $p$-methoxybenzyl) diselenide instead of bis-( $p$-methylbenzyl) diselenide. The spectral data of 9 were identical to the literature. ${ }^{19}$ The purity was confirmed by ${ }^{1} \mathrm{H} \mathrm{NMR} .{ }^{1} \mathrm{H} N M R\left(\mathrm{CDCl}_{3}\right): \delta_{\mathrm{H}}$ $1.39(9 \mathrm{H}, \mathrm{s}, t \mathrm{Bu}), 2.82(2 \mathrm{H}, \mathrm{m}, \beta \mathrm{H}), 3.68(3 \mathrm{H}, \mathrm{s}, p-\mathrm{OMe}), 3.69\left(2 \mathrm{H}, \mathrm{s}, \mathrm{CH}_{2}\right), 3.72(3 \mathrm{H}, \mathrm{s}, \mathrm{OMe}), 4.54(1 \mathrm{H}, \mathrm{m}, \alpha \mathrm{H})$, $5.22\left(1 \mathrm{H}, \mathrm{d}, J_{\mathrm{HH}} 8.0 \mathrm{~Hz}, \mathrm{NH}\right), 6.75(2 \mathrm{H}, \mathrm{m}, \mathrm{ArH}), 7.13(2 \mathrm{H}, \mathrm{m}, \mathrm{ArH}) .{ }^{13} \mathrm{C} \mathrm{NMR}\left(\mathrm{CDCl}_{3}\right): \delta_{\mathrm{C}} 25.8,27.4,28.3,52.5$, $53.4,55.3,80.2,114.0,130.0,130.6,155.1,158.6,171.7 .{ }^{77}$ Se NMR $\left(\mathrm{CDCl}_{3}\right): \delta_{\text {se }} 216.3$. 
$\boldsymbol{N}$-(tert-Butoxycarbonyl)-Se-(p-methoxybenzyl)-L-selenocysteine (2). Following similar procedures to those for the hydrolysis of $\mathbf{7}$ to $\mathbf{1}$ (vide supra), $\mathbf{2}$ was obtained from $\mathbf{9}$ as a yellow oil or white solid in $95 \%$ yield. The spectral data of 2 were identical to the literature. ${ }^{18}$ The purity was confirmed by ${ }^{1} \mathrm{H}$ NMR and HPLC. ${ }^{1} \mathrm{H}$ NMR $\left(\mathrm{CDCl}_{3}\right): \delta_{\mathrm{H}} 1.48(9 \mathrm{H}, \mathrm{s}, t \mathrm{Bu}), 2.95(2 \mathrm{H}, \mathrm{m}, \beta \mathrm{H}), 3.81\left(5 \mathrm{H}, \mathrm{s}, p\right.$-OMe and $\left.\mathrm{CH}_{2}\right), 4.63(1 \mathrm{H}, \mathrm{m}, \alpha \mathrm{H}), 5.33\left(1 \mathrm{H}, \mathrm{d}, J_{\mathrm{HH}}\right.$ $7.7 \mathrm{~Hz}, \mathrm{NH}), 6.84\left(2 \mathrm{H}, \mathrm{d}, J_{\mathrm{HH}} 8.6 \mathrm{~Hz}, \mathrm{ArH}\right), 7.21\left(2 \mathrm{H}, \mathrm{d}, J_{\mathrm{HH}} 8.6 \mathrm{~Hz}, \mathrm{ArH}\right) .{ }^{13} \mathrm{C} \mathrm{NMR}\left(\mathrm{CDCl}_{3}\right): \delta_{\mathrm{C}} 25.3,27.6,28.3$, $53.3,55.3,80.6,114.1,130.0,130.6,155.5,158.5,175.6 .{ }^{77} \mathrm{Se} \mathrm{NMR}\left(\mathrm{CDCl}_{3}\right): \delta_{\mathrm{se}} 217.3$.

$\mathbf{N}$-(9-Fluorenylmethoxycarbonyl)-L-serine (10). To a solution of L-serine (3) (103 $\mathrm{mg}, 0.98 \mathrm{mmol})$ in aqueous $10 \%$ sodium carbonate $(3 \mathrm{~mL})$ cooled on an ice bath was slowly added a solution of 9fluorenylmethoxycarbonyl chloride $(245 \mathrm{mg}, 0.95 \mathrm{mmol}$ ) in 1,4-dioxane $(3 \mathrm{~mL})$. After stirring for $1 \mathrm{~h}$ at $\mathrm{rt}$, the mixture was washed with EtOAc to remove byproducts, added with $1 \mathrm{M} \mathrm{HCl}$, and extracted with EtOAc. The organic layer was washed with brine, dried over $\mathrm{MgSO}_{4}$, and evaporated to give 10 as a white solid (284 mg, 88\%). The spectral data of 10 were identical to the literature. ${ }^{33}$ The purity was confirmed by ${ }^{1} \mathrm{H} N M R$.

$\mathbf{N}$-(9-Fluorenylmethoxycarbonyl)-L-serine methyl ester (11). To a suspension of 10 (263 $\mathrm{mg}, 0.80 \mathrm{mmol})$ in $\mathrm{MeOH}(5 \mathrm{~mL}$ ) was added concentrated sulfuric acid (3 drops). After refluxing for $3 \mathrm{~h}$, the mixture was cooled to rt. The $\mathrm{pH}$ of the reaction mixture was then adjusted to 8 with an aqueous $20 \%$ sodium carbonate solution, extracted with EtOAc. The organic layer was washed with brine, dried over $\mathrm{MgSO}_{4}$, and evaporated to give 11 as a white solid $(238 \mathrm{mg}, 87 \%)$. The spectral data of 11 were identical to the literature. ${ }^{34}$ The purity was confirmed by ${ }^{1} \mathrm{H}$ NMR.

$\mathbf{N}$-(9-Fluorenylmethoxycarbonyl)-O-(p-toluenesulfonyl)-L-serine methyl ester (12). A solution of 11 (539 mg, $1.6 \mathrm{mmol}$ ) and $p$-toluenesulfonyl chloride $(1.51 \mathrm{~g}, 7.9 \mathrm{mmol})$ in pyridine $(5 \mathrm{~mL})$ was cooled on an ice bath. After stirring for $10 \mathrm{~h}$ on an ice bath, the reaction mixture was added with water and extracted with EtOAc. The organic layer was washed with $10 \%$ potassium hydrogen sulfate, saturated sodium bicarbonate, water, and brine. The organic layer was dried over $\mathrm{MgSO}_{4}$ and evaporated. The obtained crude product (a yellow oil) was purified by silica gel column chromatography (hexane:EtOAc $=2: 1$ ) to give 12 as a pale yellow oil (762 mg, 72\%). The spectral data of 12 were identical to the literature. ${ }^{35}$ The purity was confirmed by ${ }^{1} \mathrm{H}$ NMR.

$\boldsymbol{N}$-(9-Fluorenylmethoxycarbonyl)-Se-(p-methoxybenzyl)-L-selenocysteine methyl ester (13). To a solution of 12 (122 mg, $0.25 \mathrm{mmol})$ and bis-( $p$-methoxybenzyl) diselenide (100 mg, $0.25 \mathrm{mmol})$ in $\mathrm{MeOH}(4 \mathrm{~mL})$ and Et ${ }_{2} \mathrm{O}$ $(6 \mathrm{~mL})$ cooled on an ice bath was added sodium borohydride until the solution color disappeared. After stirring for $30 \mathrm{~min}$, water was added to the reaction solution, and the mixture was extracted with EtOAc. The organic layer was washed with brine, dried over $\mathrm{MgSO}_{4}$, and evaporated. The obtained crude product (a yellow oil) was purified by silica gel column chromatography (hexane:EtOAc $=2: 1$ ) to give 13 as a pale yellow oil (101 mg, 78\%). The spectral data of 13 were identical to the literature. ${ }^{36}$ The purity was confirmed by ${ }^{1} \mathrm{H}$ NMR and HPLC. ${ }^{1} \mathrm{H} \mathrm{NMR}\left(\mathrm{CDCl}_{3}\right): \delta_{\mathrm{H}} 2.95(2 \mathrm{H}, \mathrm{m}, \beta \mathrm{H}), 3.77\left(2 \mathrm{H}, \mathrm{s}, \mathrm{PhCH}_{2}\right), 3.79(3 \mathrm{H}, \mathrm{s}, p-\mathrm{OMe}), 3.80(3 \mathrm{H}, \mathrm{s}, \mathrm{OMe}), 4.27\left(1 \mathrm{H}, \mathrm{t}, J_{\mathrm{HH}}\right.$ $7.1 \mathrm{~Hz}, \mathrm{Fmoc}-\mathrm{CH}), 4.44\left(2 \mathrm{H}, \mathrm{d}, J_{\mathrm{HH}} 7.1 \mathrm{~Hz}, \mathrm{Fmoc}-\mathrm{CH}_{2}\right), 4.70(1 \mathrm{H}, \mathrm{m}, \alpha \mathrm{H}), 5.57\left(1 \mathrm{H}, \mathrm{d}, J_{\mathrm{HH}} 8.0 \mathrm{~Hz}, \mathrm{NH}\right), 6.85(2 \mathrm{H}, \mathrm{d}$, $\left.J_{H H} 8.6 \mathrm{~Hz}, \mathrm{~m}, \mathrm{ArH}\right), 7.22\left(2 \mathrm{H}, \mathrm{d}, J_{\mathrm{HH}} 8.5 \mathrm{~Hz}, \mathrm{ArH}\right), 7.34(2 \mathrm{H}, \mathrm{m}, \mathrm{ArH}), 7.42(2 \mathrm{H}, \mathrm{m}, \mathrm{ArH}), 7.63\left(2 \mathrm{H}, \mathrm{t}, J_{\mathrm{HH}} 7.1 \mathrm{~Hz}\right.$, $\mathrm{ArH}), 7.79(2 \mathrm{H}, \mathrm{m}, \mathrm{ArH}) .{ }^{13} \mathrm{C} \mathrm{NMR}\left(\mathrm{CDCl}_{3}\right): \delta_{\mathrm{C}} 25.7,27.5,47.1,52.7,53.8,55.3,67.2,114.0,120.0,125.1,127.1$, $127.8,130.0,130.5141 .3,143.7,158.6,171.4 .{ }^{77}$ Se NMR $\left(\mathrm{CDCl}_{3}\right): \delta_{\mathrm{se}} 214.7$.

Synthesis of 13 via iodide 14. Under nitrogen atmosphere, triphenyl phosphine (124 mg, $0.47 \mathrm{mmol}$ ) and imidazole (40 mg, $0.58 \mathrm{mmol}$ ) were dissolved in dry dichloromethane $(3 \mathrm{~mL}$ ). To this solution cooled on an ice bath was added iodine (124 $\mathrm{mg}, 0.49 \mathrm{mmol})$. The mixture was stirred at $\mathrm{rt}$ for $10 \mathrm{~min}$ and then cooled on an ice bath again. To the resulting yellow suspension was added a solution of 11 (111 $\mathrm{mg}, 0.33 \mathrm{mmol})$ in dry dichloromethane $(3 \mathrm{~mL})$. After stirring for $2 \mathrm{~h}$ on an ice bath, the reaction mixture (a yellow suspension) was filtered, and the filtrate was evaporated to give crude iodide $\mathbf{1 4}$ as an orange oil. In the meantime, bis-( $p$ methoxybenzyl) diselenide $(70.5 \mathrm{mg}, 0.18 \mathrm{mmol}$ ) were suspended in $\mathrm{MeOH}(2 \mathrm{~mL})$, and the mixture was 
cooled on an ice bath and then added with sodium borohydride until the solution color disappeared. To the resulting solution was slowly added a solution of obtained 14 in $\mathrm{Et}_{2} \mathrm{O}(6 \mathrm{~mL})$ and $\mathrm{MeOH}(2 \mathrm{~mL})$. After stirring for $1 \mathrm{~h}$ on an ice bath, water was added to the reaction solution, and the mixture was extracted with EtOAc. The organic layer was washed with brine, dried over $\mathrm{MgSO}_{4}$, and evaporated. The obtained crude product (a yellow oil) was purified by gel permeation chromatography (chloroform) to give 13 as a colorless oil (58.5 mg, $34 \%$ from 11). lodide 14 was unstable on silica gel, so crude 14 was used for the subsequent selenation without purification. Product 13 was recrystallized from dichloromethane-hexane repeatedly.

$\boldsymbol{N}$-(9-Fluorenylmethoxycarbonyl)-Se-(p-methoxybenzyl)-L-selenocysteine (15). A mixture of 14 (790 mg, 1.5 $\mathrm{mmol}$ ) and trimethyltin hydroxide (989 $\mathrm{mg}, 5.5 \mathrm{mmol}$ ) was dissolved in dry 1,2-dichloroethane (15 $\mathrm{mL})$. After stirring overnight at $35^{\circ} \mathrm{C}$, the mixture was filtered, and the filtrate was evaporated. The resulting crude product was purified by silica gel column chromatography (hexane:EtOAc $=2: 1$ to $0: 1$ ) to give 15 as a colorless oil or white solid (702 mg, 91\%). The spectral data of $\mathbf{1 5}$ were identical to the literature. ${ }^{37}$ The purity was confirmed by ${ }^{1} \mathrm{H}$ NMR and HPLC. ${ }^{1} \mathrm{H}$ NMR $\left(\mathrm{CDCl}_{3}\right): \delta_{\mathrm{H}} 2.98(2 \mathrm{H}, \mathrm{m}, \mathrm{\beta H}), 3.78(3 \mathrm{H}, \mathrm{s}, \mathrm{p}-\mathrm{OMe}), 3.79\left(2 \mathrm{H}, \mathrm{s}, \mathrm{CH}_{2}\right)$, $4.26\left(1 \mathrm{H}, \mathrm{t}, J_{\mathrm{HH}} 6.8 \mathrm{~Hz}, \mathrm{Fmoc}-\mathrm{CH}\right), 4.45\left(1 \mathrm{H}, \mathrm{d}, J_{\mathrm{HH}} 6.7 \mathrm{~Hz}, \mathrm{Fmoc}_{-} \mathrm{CH}_{2}\right), 4.70(1 \mathrm{H}, \mathrm{m}, \alpha \mathrm{H}), 5.54\left(1 \mathrm{H}, \mathrm{d}, J_{\mathrm{HH}} 7.8 \mathrm{~Hz}\right.$, $\mathrm{NH}), 6.83\left(2 \mathrm{H}, \mathrm{d}, J_{\mathrm{HH}} 8.4 \mathrm{~Hz}, \operatorname{ArH}\right), 7.20\left(2 \mathrm{H}, \mathrm{d}, J_{\mathrm{HH}} 8.3 \mathrm{~Hz}, \operatorname{ArH}\right), 7.33(2 \mathrm{H}, \mathrm{m}, \operatorname{ArH}), 7.42(2 \mathrm{H}, \mathrm{m}, \operatorname{ArH}), 7.63(2 \mathrm{H}, \mathrm{t}$, $\left.J_{\mathrm{HH}} 6.7 \mathrm{~Hz}, \mathrm{ArH}\right), 7.78(2 \mathrm{H}, \mathrm{m}, \mathrm{ArH}) .{ }^{13} \mathrm{C} \mathrm{NMR}\left(\mathrm{CDCl}_{3}\right): \delta_{\mathrm{C}} 25.1,27.7,47.1,53.6,55.3,67.3,114.1,120.0,125.1$, $127.1,127.8,130.0,141.3,143.6,158.7 .{ }^{77} \mathrm{Se} \mathrm{NMR}\left(\mathrm{CDCl}_{3}\right): \delta_{\mathrm{Se}} 216.7$.

Optical resolution of $\mathbf{1}, \mathbf{2}, \mathbf{1 3}$, and $\mathbf{1 5}$. Racemic samples were obtained from DL-serine following the same synthetic procedures described above. Samples were dissolved in acetonitrile. The solution $(10 \mu \mathrm{L})$ was injected onto the HPLC system equipped with a chiral column set in column oven at $35{ }^{\circ} \mathrm{C}$. The absorption was detected at $280 \mathrm{~nm}$ under an isocratic solvent condition. For optical resolution of 1 and 2, Chiralpak AD-RH (Daicel; $0.46 \phi \times 15 \mathrm{~cm}$ ) was employed as a column, and $40 \%$ acetonitrile in water containing $0.1 \%$ phosphoric acid was used as a solvent at a flow rate of $1 \mathrm{~mL} / \mathrm{min}$ for 1 or $0.8 \mathrm{~mL} / \mathrm{min}$ for 2 . For optical resolution of 13 and 15. Chiralcel OD-RH (Daicel; $0.46 \phi \times 15 \mathrm{~cm}$ ) was employed as a column. $70 \%$ or $60 \%$ acetonitrile in water containing $0.1 \%$ phosphoric acid was used as a solvent at a flow rate of 0.8 or $1.0 \mathrm{~mL} / \mathrm{min}$, respectively.

\section{Acknowledgements}

We thank Professor Shuji Kodama (Tokai University) for optical resolution of selenocysteine derivatives and Kazuma Shinjo (Tokai University) for assistance in the synthesis of diselenides MBnSeSeMBn and MPMSeSeMPM. This work was supported by Research and Study Project of Tokai University, Educational System General Research Organization.

\section{References}

1. Arner, E. S. J. Exp. Cell Res. 2010, 316, 1296, and references cited therein.

http://dx.doi.org/10.1016/j.yexcr.2010.02.032

2. Hawkes, W. C.; Alkan, Z. Biol. Trace Elem. Res. 2010, 134, 235.

http://dx.doi.org/10.1007/s12011-010-8656-7

3. Bhabak, K. P.; Mugesh, G. Acc. Chem. Res. 2010, 43, 1408, and references cited therein. http://dx.doi.org/10.1021/ar100059g 
4. Iwaoka, M. In Organoselenium Chemistry: Between Synthesis and Biochemistry; Santi, C. Ed.; Bentham Science Publishers, 2014, p 361, and references cited therein.

http://dx.doi.org/10.2174/9781608058389114010015

5. Iwaoka, M. In Biochalcogen Chemistry: The Biological Chemistry of Sulfur, Selenium, and Tellurium; Bayse, C. A.; Brumaghim, J. L. Eds.; American Chemical Society, 2013, Vol. 1152, p 163, and references cited therein.

http://dx.doi.org/10.1021/bk-2013-1152.ch008

6. Casi, G.; Hilvert, D. J. Biol. Chem. 2007, 282, 30518.

http://dx.doi.org/10.1074/jbc.M705528200

7. Yoshida, S.; Kumakura, F.; Komatsu, I.; Arai, K.; Onuma, Y.; Hojo, H.; Singh, B. G.; Priyadarsini, K. I.; Iwaoka, M. Angew. Chem. Int. Ed. 2011, 50, 2125.

http://dx.doi.org/10.1002/anie.201006939

8. Takei, T.; Urabe, Y.; Asahina, Y.; Hojo, H.; Nomuta, T.; Dedachi, K.; Arai, K.; Iwaoka, M. J. Phys. Chem. $B$ 2014, 118, 492.

http://dx.doi.org/10.1021/jp4113975

9. Turanov, A. A.; Xu, X.-M.; Carlson, B. A.; Yoo, M.-H.; Gladyshev, V. N.; Hatfield, D. L. Adv. Nutr. 2011, 2, 122.

http://dx.doi.org/10.3945/an.110.000265

10. Xu, J.; Croitoru, V.; Rutishauser, D.; Cheng, Q.; Arner, E. S. J. Nucl. Acids Res. 2013, 41, 9800. http://dx.doi.org/10.1093/nar/gkt764

11. Muttenthaler, M.; Alewood, P. F. J. Pept. Sci. 2008, 14, 1223, and references cited therein. http://dx.doi.org/10.1002/psc.1075

12. Metanis, N.; Keinan, E.; Dawson, P. D. J. Am. Chem. Soc. 2006, 128, 16684.

http://dx.doi.org/10.1021/ja0661414

13. Flemer, S., Jr. J. Pept. Sci. 2015, 21, 53, and references cited therein.

http://dx.doi.org/10.1002/psc.2723

14. Hondal, R. J.; Nilsson, B. L.; Raines, R. T. J. Am. Chem. Soc. 2001, 123, 5140.

http://dx.doi.org/10.1021/ja005885t

15. Gieselman, M. D.; Xie, L.; van der Donk, W. A. Org. Lett. 2001, 3, 1331.

http://dx.doi.org/10.1021/ol0157120

16. Quaderer, R.; Sewing, A.; Hilvert, D. Helv. Chim. Acta 2001, 84, 1197.

http://dx.doi.org/10.1002/1522-2675(20010516)84:5<1197::AID-HLCA1197>3.0.CO;2-\#

17. Flemer, S., Jr. Molecules 2011, 16, 3232.

http://dx.doi.org/10.3390/molecules16043232

18. Flögel, O.; Casi, G.; Hilvert, D.; Seebach, D. Helv. Chim. Acta 2007, 90, 1651.

http://dx.doi.org/10.1002/hlca.200790171

19. Braga, A. L.; Wessjohann, L. A.; Taube, P. S.; Galetto, F. Z.; Andrede, F. M. Synthesis 2010, $18,3131$. http://dx.doi.org/10.1055/s-0030-1258188

20. Painter, E. P. J. Am. Chem. Soc. 1947, 69, 229.

http://dx.doi.org/10.1021/ja01194a013

21. Block, E.; Birringer, M.; Jiang, W.; Nakahodo, T.; Thompson, H. J.; Toscano, P. J.; Uzar, H.; Zhang, X.; Zhu, Z. J. Agric. Food Chem. 2001, 49, 458.

http://dx.doi.org/10.1021/jf001097b

22. Chocat, P.; Esaki, N; Tanaka, H; Soda, K. Anal. Biochem. 1985, 148, 485. 
http://dx.doi.org/10.1016/0003-2697(85)90256-8

23. Stocking, E. M.; Schwarz, J. N.; Senn, H.; Salzmann, M.; Silks, L. A. J. Chem. Soc., Perkin Trans. 1 1997, 2443.

http://dx.doi.org/10.1039/a600180g

24. Siebum, A. H. G.; Woo, W. S.; Raap, J.; Lugtenburg, J. Eur. J. Org. Chem. 2004, 2905. http://dx.doi.org/10.1002/ejoc.200400063

25. Phadnis, P. P.; Mugesh, G. Org. Biomol. Chem. 2005, 3, 2476.

http://dx.doi.org/10.1039/b505299h

26. Narayanaperumal, S.; Alberto, E. E.; Gul, K.; Kawasoko, C. Y.; Dornelles, L.; Rodrigues, O. E. D. Braga, A. L. Tetrahedron 2011, 67, 4723.

http://dx.doi.org/10.1016/j.tet.2011.04.018

27. Mobli, M,; de Araújo, A. D.; Lambert, L. K.; Pierens, G. K.; Windley, M. J.; Nicholson, G. M.; Alewood, P. F.; King, G. F. Angew. Chem. Int. Ed. 2009, 48, 9312.

http://dx.doi.org/10.1002/anie.200905206

28. Kawai, Y.; Ando, H.; Ozeki, H.; Koketsu, M.; Ishihara H. Org. Lett. 2005, 7, 4653.

http://dx.doi.org/10.1021/ol051804s

29. Iwaoka, M.; Haraki, C.; Ooka, R.; Miyamoto, M.; Sugiyama, A.; Kohara, Y.; Isozumi, N. Tetrahedron Lett. 2006, 47, 3861.

http://dx.doi.org/10.1016/j.tetlet.2006.03.177

30. Iwaoka, M.; Ooka, R.; Nakazato, T.; Yoshida, S.; Oishi, S. Chem. Biodiversity 2008, 5, 359. http://dx.doi.org/10.1002/cbdv.200890037

31. Trost, B. M.; Rudd, M. T. Org. Lett. 2003, 5, 4599. http://dx.doi.org/10.1021/ol035752n

32. Cagnoli, R.; Lanzi, M.; Mucci, A.; Parenti, F.; Schenetti, L. Synthesis 2005, 267. http://dx.doi.org/10.1055/s-2004-834930

33. Pianowski, Z. L.; Winssinger, N. Chem. Commun. 2007, 3820. http://dx.doi.org/10.1039/b709611a

34. Harayama, Y.; Yoshida, M.; Kamimura, D.; Wada, Y.; Kita, Y. Chem. Eur. J. 2006, 12, 4893. http://dx.doi.org/10.1002/chem.200501635

35. Tabanella, S.; Valancogne, I.; Jackson, R. F. W. Org. Biomol. Chem. 2003, 1, 4254. http://dx.doi.org/10.1039/b308750f

36. Schroll, A. L.; Hondal, R. J.; Flemer, S., Jr. J. Pept. Sci. 2012, 18, 155. http://dx.doi.org/10.1002/psc.1430

37. Koide, T.; Itoh, H.; Otaka, A.; Yasui, H.; Kurada, M.; Esaki, N.; Soda, K.; Fujii, N. Chem. Pharm. Bull. 1993, 41, 502. http://dx.doi.org/10.1248/cpb.41.502 